\title{
Impact of Fat Replacement by Core-shell Microparticles on Set Type Yoghurts: Study of Their Physicochemical, Textural and Microstructural Properties
}

Verónica Yonaha ${ }^{\mathrm{a}}$, María J. Martinez ${ }^{\mathrm{b}}$, Mariana C. Allievi ${ }^{\mathrm{c}}$, Federico Coluccio Leskow ${ }^{\mathrm{c}}$ and Oscar E. Pérez ${ }^{\mathrm{c}, \mathrm{d}, *}$

${ }^{a}$ Departamento de Industrias, Facultad de Ciencias Exactas y Naturales, Universidad de Buenos Aires, Intendente Güiraldes, s/n, Ciudad Universitaria, Buenos Aires, CP 1428, Argentina; ${ }^{b}$ Departamento de Industrias, Facultad de Ciencias Exactas y Naturales, Consejo Nacional de Investigación Científica y Técnicas de la República Argentina, ITAPROQ-CONICET, Universidad de Buenos Aires, Intendente Güiraldes, s/n, Ciudad Universitaria, Buenos Aires, CP 1428, Argentina; ${ }^{c}$ Departamento de Química Biológica, Facultad de Ciencias Exactas y Naturales, Consejo Nacional de Investigación Científica y Técnicas de la República Argentina IQUIBICEN-CONICET, Universidad de Buenos Aires, Intendente Güiraldes, s/n, Ciudad Universitaria, Buenos Aires, CP 1428, Argentina; ${ }^{d}$ Departamento de Desarrollo Productivo y Tecnológico, Universidad Nacional de Lanús, 29 de Setiembre 3901, B1832 Remedios de Escalada, Buenos Aires, Argentina

ARTICLE H IS TORY

Received: February 01, 2018 Revised: April 17, 2018 Accepted: April 18, 2018

DOI:

10.2174/1573401314666180503154304

CrossMark

\begin{abstract}
Background: Core-shell micro and nanoparticles can be used to encapsulate bioactive or functional components and to replace fat content also, since they are able to mimic the organoleptic characteristics of the fat globules.
\end{abstract}

Objective: The aim of this study was to investigate the effect of replacing milk fat matter by core-shell microparticles in set type yoghurt.

Method: Microparticles were produced by electrostatic deposition of carboxymethylcellulose (CMC) on thermally induced aggregates of $\beta$-lactoglobulin $(\beta-\lg )_{n}$. Laboratory made yoghurts were prepared with: full fat milk (F), low fat milk (L) and low fat milk with CS microparticles (CS). Yoghurts properties (e.g. physicochemical, rheological, textural) were characterized during storage at $4{ }^{\circ} \mathrm{C}$. Trials were also conducted in commercial yoghurts taken as references.

Results: Water holding capacity (WHC) and elastic modulus $\left(\mathrm{G}^{\prime}\right)$ of $\mathrm{CS}$ yoghurts resulted similar to commercial yoghurts. Color properties $\left(\mathrm{L}^{*}, \mathrm{a}^{*} . \mathrm{b}^{*}\right)$ were slightly altered and showed no significant variation upon time. CS yoghurts behaved as a weak gel as indicated by the higher $\mathrm{n}$ values obtained from mechanical spectra and by the lower firmness obtained from texture measurements. Important differences were observed in microstructure. CS yoghurts showed homogeneous aspect with large aggregates and empty spaces. Bacterial growth in CS yoghurts resulted similar to low fat yoghurts.

Conclusion: Replacement of milk fat by core-shell microparticles would be feasible giving a final product without major differences, at least instrumentally measurable, to commercial yogurt.

Keywords: Carboxymethylcellulose, core-shell microparticles, fat replacers, nanoparticles, yoghurt, $\beta$-lactoglobulin.

\section{INTRODUCTION}

Yoghurt is the product obtained by coagulation of milk as a consequence of lactic fermentation by cultures of Lactobacillus delbrueckii subsp. bulgaricus and Streptococcus thermophilus and $\mathrm{pH}$ decrease.

*Address correspondence to this author at the Departamento de Química Biológica, Facultad de Ciencias Exactas y Naturales, Intendente Güiraldes, s/n, Ciudad Universitaria, Buenos Aires, CP 1428, Argentina;

Tel/Fax: +54-11-4576-3342; E-mail: oscarperez@qb.fcen.uba.ar
Core-shell microparticles can be constructed by mixing biopolymers (proteins and charged polysaccharides) solutions at $\mathrm{pH}$ and ionic strength in which both species have opposite electrostatic net charge by applying the electrostatic deposition concept $[1,2]$.

In this context, the use of biopolymers in a combined way has gained importance because of the synergistic interactions that provide the ability to control and improve food texture [3]. 
Certain polysaccharides considered dietary fiber have been shown to have potential beneficial health effects, such as lowering cholesterol, preventing cancer or improve colon health [4]. Between them, CMC is a cellulose derivative in which some of the hydroxyl groups are substituted with carboxymethyl groups. It is an anionic, linear, water soluble polymer [5]. Some applications in the industry are as thickener because of its water binder capacity, in the oil industry as a lubricant for drilling, emulsions stabilizer [6]. It is nontoxic, biodegradable and biocompatible, it also possesses good barrier properties [7].

$\beta$-Lactoglobulin ( $\beta-\lg )$ is the most abundant protein in the whey protein (nearly $50-55 \%$ ) [8]. Whey is the principal byproduct of dairy industry obtained during the manufacture of cheese [9]. $\beta$-lg can form aggregates by heating. In fact, in the previous work [10] we obtained core-shell microparticles by mixing thermally aggregated $\beta-\lg$ (core) and CMC solution (shell) at $\mathrm{pH} \mathrm{7,} \mathrm{and} \mathrm{decreasing} \mathrm{the} \mathrm{pH}$ up to 4 to promote the adsorption of CMC on the protein core due to their opposite electric charge.

Core-shell micro and nanoparticles have applications in food, pharmaceutical and health care. They can be used to encapsulate, protect or control the delivery of bioactive or functional components such as minerals, peptides, proteins, enzymes, drugs, lipids or dietary fiber [11, 12]. They can also be used to reduce the fat content through their ability to mimic the properties of the fat globules such as its ability to scatter light, increase viscosity and modify the organoleptic characteristics [13].

The aim of this work was to study the impact of milk fat replacement by core-shell microparticles in set type yoghurt on the physicochemical, rheological and textural properties of the product. Microorganism viability was also evaluated as it is implied in the fermentation process.

\section{MATERIALS AND METHOD}

\subsection{Materials}

BioPURE $\beta$-lg was supplied by DAVISCO Foods International, Inc. (Le Sueur, Minnesota, United States). Its composition was: protein (dry basis) $97.8 \%$ being $\beta$-lg $93.6 \%$ of total proteins, fat $0.3 \%$, ash $1.8 \%$ and moisture $5.0 \%$. $\mathrm{CMC}$, commercial designation E466, was provided by CDIA S.R.L. Argentina, with a degree of substitution 0.75 0.95 , purity $99.5 \%$ and moisture $10 \%$. Molecular weight of $\mathrm{CMC}$ is $17000 \mathrm{Da}$ with a degree of polymerization equal to 100 (data from the supplier). Viscosity, measured on $1 \%$ aqueous solution of $\mathrm{CMC}$, at $25^{\circ} \mathrm{C}$, was $4000 \pm 400 \mathrm{cP}$ as determined by Brookfield RVT viscometer (20 rpm, sp 3).

$\beta-\lg$ and $\mathrm{CMC}$ were dissolved in Milli-Q water under continuous stirring and the $\mathrm{pH}$ were adjusted by addition of citric acid. Ingredients for set yoghurt preparation were whole and skim milk powder from Sancor Coop. UnidasLtda, Santa Fe, Argentina; which were reconstituted by dissolution in the proper amount of water. Frozen bacteria starter for yoghurt containing Lactobacillus delbrueckii subsp. bulgaricusand Streptococcus thermophilus, was kindly given by Amerex Argentina.

\subsection{Methods}

\subsubsection{Core-shell Microparticles Preparation and Size De- termination}

Core-shell microparticles were prepared by applying the electrostatic deposition concept as it was explained in the previous work [10]. $0.5 \%$ of $\beta$-lg solution was heated at $90^{\circ} \mathrm{C}$ for $20 \mathrm{~min}$ at $\mathrm{pH} 7$ in order to obtain thermically aggregated $\beta-\lg$ (core, $\beta-\lg _{\mathrm{n}}$ ). The shell was formed by CMC electrostatic deposition by mixing $(\beta-\lg )_{\mathrm{n}}$ microparticles $(0.5$ $\% \mathrm{w} / \mathrm{w})$ with $\mathrm{CMC}$ solutions $(0.6 \% \mathrm{w} / \mathrm{w})$ at $\mathrm{pH} 7.0$, and further decrease up to 4.0 promoting thus the electrostatic adsorption of the negative polysaccharide on the positive charged $(\beta-\lg )_{\mathrm{n}}$ surface. The final biopolymers concentrations in solution were 0.25 and $0.3 \% \mathrm{w} / \mathrm{w}$ for $(\beta-\lg )_{\mathrm{n}}$ and $\mathrm{CMC}$, respectively. Finally, core-shell microparticles were isolated from the aqueous phase by centrifugation in a DupontSorvall RC-5 (Newton, CT, USA) device at 10000 rpm for $60 \mathrm{~min}$. After discarding the supernatant, the material was freeze dried in a HetoHolten A/S, cooling trap model CT 110 freeze-dryer (Heto Lab Equipment, Denmark) operating at a condenser plate temperature of $-111^{\circ} \mathrm{C}$, a chamber pressure of $30 \mathrm{~Pa}$, and shelf temperature of $25^{\circ} \mathrm{C}$.

\subsubsection{Static Laser Light Scattering (SLS)}

The core-shell microparticles size were verified by SLS in a Mastersizer 2000 device equipped with the dispersion unit Hydro 2000MU, Malvern Instruments Ltd (Worcestershire, UK). The pump speed was settled at $1300 \mathrm{rpm}$. The Refractive Index (RI) of the disperse phase (1.354) and its absorption parameter (0.001) were used. Particle size is reported as $\mathrm{D}_{32}$ and $\mathrm{D}_{43}$ diameters. $\mathrm{D}_{32}$ is the volume-surface mean diameter or Sauter diameter $\left(\mathrm{D}_{32}=\Sigma \mathrm{n}_{\mathrm{i}} \mathrm{d}_{\mathrm{i} 3} / \Sigma \mathrm{ni} \mathrm{d}_{\mathrm{i} 2}\right)$ where $n_{i}$ is the number of particles of diameter $[14,15]$. $D_{43}$ is the equivalent volume-mean diameter or De Broucker diameter $\left(\mathrm{D}_{43}=\Sigma\right.$ ni $\left.\mathrm{di}_{4} / \Sigma \mathrm{ni} \mathrm{di}_{3}\right)$, where $\mathrm{n}_{\mathrm{i}}$ is the number of particles of diameter $d_{i}[16,17]$. The particle sizes are reported as the average and standard deviation of ten readings made on two independently prepared samples.

\subsubsection{Yoghurt Elaboration}

Three batches of $1 \mathrm{~L}$ of each one of three different set type yoghurt formulations was prepared: full fat (F), low fat (L) and fat fully substituted with CS microparticles (CS). Total solids content enhancement is recommended in bovine milk destined to yoghurt preparation [18]. To this end, powder skim milk was added to water to give the amount of solids shown in Table 1. Sucrose $10 \%(\mathrm{w} / \mathrm{w})$ was added to each formulation.

Solids ingredients (including core-shell microparticles) were dispersed under stirring at $50 \pm 1^{\circ} \mathrm{C}$ and then heated at $85 \pm 1^{\circ} \mathrm{C}$ for $20 \mathrm{~min}$ for present bacteria inactivation, whey proteins denaturation and the complex formation between whey proteins at the micelle surface [19]. Subsequently, mixtures were cooled up to $43 \pm 1^{\circ} \mathrm{C}$ in a water/ice bath. After cooling, milk was inoculated with the previously activated starter culture (frozen bacteria starter, $40 \mathrm{mg}$, dissolved in milk, $20 \mathrm{ml}$, and incubated at $32^{\circ} \mathrm{C}$ over night up to $\mathrm{pH} 4.2$ 4.4). Immediately after inoculation, $100 \mathrm{~mL}$ of each formulation was poured into rigid plastic vessels. Fermentation was carried out at $43 \pm 1{ }^{\circ} \mathrm{C}$ by putting vessels in an incubator 
device. Once the $\mathrm{pH}$ of media reached 4.6 , the process was stopped by refrigerating samples at $4 \pm 0.1{ }^{\circ} \mathrm{C}$, condition at which they were kept up to the corresponding analysis.

Commercial yogurts were chosen as a reference because they are highly accepted by consumers. Even commercial products could be different as the manufacture process and while the real formulations were different, the comparison results were relevant. Table 2 shows the fat content declared by the companies. Table $\mathbf{1}$ of the supplementary material shows the ingredients of each commercial yogurt. The analysis of all samples were carried out at a temperature of $10^{\circ} \mathrm{C}$ corresponding to the common serving temperature for sensory evaluation of fermented dairy products [20].

Table 1. Percentage composition of solids total in the laboratory made yoghurt formulations.

\begin{tabular}{|c|c|c|c|}
\hline \multirow{2}{*}{ g / 100 mL milk } & \multicolumn{3}{|c|}{ Yoghurt Type Formulations } \\
\cline { 2 - 4 } & F & L & CS \\
\hline \hline Non Fat Solids & 8.3 & 8.6 & 8.6 \\
\hline Fat Solids & 3.4 & 0 & 0 \\
\hline Non Fat Solids & 3.7 & 6.8 & 3.4 \\
\hline Core-Shell Microparticles & 0 & 0 & 3.4 \\
\hline Total solids & 15.4 & 15.4 & 15.4 \\
\hline
\end{tabular}

Table 2. Percentage composition in fat solids for commercial yoghurt. LC1: 1st commercial brand low fat set yoghurt; LC2: 2nd commercial brand low fat set yoghurt; FC1: 1st commercial brand full fat set yoghurt and FC2: 2nd commercial brand full fat set yoghurt.

\begin{tabular}{|c|c|c|c|c|}
\hline \multirow{2}{*}{ g / 100 mL milk } & \multicolumn{4}{|c|}{ Commercial Yoghurt } \\
\cline { 2 - 5 } & LC1 & LC2 & FC1 & FC2 \\
\hline \hline Fat Solids & 0.0 & 0.0 & 3.0 & 2.0 \\
\hline
\end{tabular}

\subsubsection{Physicochemical Determinations}

Yoghurts $\mathrm{pH}$ was measured every half hour during fermentation process and at 7, 14, 21 and 28 days during the storage at $4^{\circ} \mathrm{C}$ by using an Orion 3 Star pHmeter (Thermo Scientific, USA). Three replicates of each measurement were carried out for each formulation and storage time. Acidity measurement was also made during fermentation process and storage by titration of $10 \mathrm{~mL}$ of each sample with $0.1 \mathrm{~N}$ of sodium hydroxide $(\mathrm{NaOH})$, and phenolphthalein. Lactic acid is the principal acidic compound contributing to whole yoghurt acidity. This parameter was expressed as Dornic degree $\left({ }^{\circ} \mathrm{D}\right)[21]$.

Water holding capacity (WHC) was determined by the method of Abbasi et al. [22]. $2 \mathrm{~g}$ of yoghurt were disposed in especially designed acrylic tubes for micro centrifuge. Samples were then centrifuged at $5600 \mathrm{~g}$ for 5 minutes in a Costar Model 10 Mini Centrifuge. After that the supernatants was discarded and the weight of remnant gel taken. WHC was calculated as Eq. 1:

$\% W H C=\left(m_{f} / m_{0}\right) * 100$

where: $m_{0}$ is the initial yoghurt sample mass $(\mathrm{g})$ and $m_{f}$ is the sample mass after centrifugation.

Colour was measured by using a spectrocolorimeter (CM-3600d, Minolta Co., Tokyo, Japan). Containers were deep enough to avoid the influence of the background in colour measurements. CIE L*a*b* coordinates was obtained at $10^{\circ}$ and the illuminant, D65, emulates the averaged sun light. Colour measurements were made in triplicate.

\subsubsection{Textural Evaluation}

Yoghurt textural properties, i.e. firmness, cohesiveness, adhesiveness, were obtained by the back extrusion tests. To this end a universal Texture Analyser TA-XT2 (Stable Micro Systems, UK), with a ring probe (a back extrusion probe of $35 \mathrm{~mm}$ of diameter) was used and controlled by a PC computer. The probe penetrated $10 \mathrm{~mm}$, at a rate of $1 \mathrm{~mm} / \mathrm{s}$ into $100 \mathrm{~mL}$ of yoghurt contained in a vessel (diameter $55 \mathrm{~mm}$ ). Force-time dependence plots obtained in the test were analyzed using the Texture Expert for Windows v. 1.05 program (Stable Micro Systems, UK).

\subsubsection{Rheological Measurements}

Viscoelastic behaviour characterization was performed by an oscillatory test obtaining the respective mechanical spectra in a Paar Physica controlled stress Rheometer (MCR 300). $0.8 \mathrm{~g}$ of gel yoghurts were carefully put onto the bottom plate of a parallel plate (diameter $30 \mathrm{~mm}$ ) measuring system, gap $1 \mathrm{~mm}$. As the yogurt samples were manipulated to be placed on the rheometer, 5 minutes before measuring to ensure stabilization of the gel structure. The temperature of the bottom plate was controlled with a Peltier system (Viscotherm VT2, PaarPhysica) and kept at $10^{\circ} \mathrm{C}$. Frequency sweeps ranged $0.1-10 \mathrm{~Hz}$ and the strain was kept at $0.01 \%$, a value found to be in the linear viscoelastic region in preliminary experimentation. The rheological parameters $\mathrm{G}^{\prime}, \mathrm{G}^{\prime \prime}$ and $\tan \delta$ were derived using the program Rheoplus/32 v. 3.10. It is important to clarify that deformations used in this test are not those made into the mouth, where irreversible deformations are made; however, it is assumed that the viscoelastic properties may give an indication of the initial experience of the consumer [23]. $G^{\prime}$ - frequency dependence was expressed through the constant $n$, which gives information about the gel structure [24] by mean of the Eq. 2:

$\log G^{\prime}=n \log f+K$

where, $G^{\prime}$ is the elastic modulus, $f$ is the frequency and $K$ is a constant.

\subsubsection{Microstructure: Confocal Laser Scanning Microsco- py (CLSM)}

Yoghurts microstructure was observed using CLSM, following the method described in Ciron et al. [25]. Images were taken in an Olympus Fluoview FV1000 microscope (Center Valley, PA, USA). An Olympus water immersion 60x objective (1.20 N.A. UPLAN APO) objective was used. Samples were dual-labelled using Rodamine B (excitation, $543 \mathrm{~nm}$; emission, BP 560-620 nm); and Congo Red (excita- 
tion, $488 \mathrm{~nm}$; emission $>650 \mathrm{~nm}$ ). The first fluorophore has high affinity with proteins and peptides while the second one is lipophilic. Sequential mode analysis was used for imaging and images were processed with Image $J$, the background of each channel was subtracted and no filters were applied.

\subsubsection{Viable Cells Count Determination}

Lactobacillus sp and Streptococcus sp counts were determined as described by Dave et al. [26]. Bacterial viable counts, expressed as colony forming unit per milliliter $(\mathrm{CFU} / \mathrm{mL})$, in yoghurts were performed from serial decimal dilutions in $0.85 \%$ sodium chloride $(\mathrm{NaCl})$ solutions. Then plating on MRS agar (de Man, Rogosa and Sharpe; 1.5\% agar, BioKar), pH 5.4 $\pm 0.1 .1 \mathrm{~mL}$ of each sample was diluted with $9 \mathrm{~mL}$ of sterile saline solution to obtain the initial dilution $\left(10^{-1}\right)$. Subsequent 10 -fold serial dilutions were made with saline solution, and $0.1 \mathrm{~mL}$ of the diluted samples was spread on MRS agar. After anaerobic incubation at $37^{\circ} \mathrm{C}$ for $48-72 \mathrm{~h}, \mathrm{CFU} / \mathrm{mL}$ was calculated. Survival and growth for each strain was determined on days 7 and 21 .

\subsubsection{Statistical Analysis}

All determinations were made at least in triplicate in three individual samples and each value represents the mean \pm SD of yoghurts from independently elaboration processes. Significant differences were determined by ANOVA test using the general linear model procedure (Statgraphics 3.0). An alpha level of $0.05(\mathrm{p}<0.05)$ was used to determine significance.

\section{RESULTS AND DISCUSSIONS}

\subsection{Particle Size}

Particle size distribution of $(\beta-\lg )_{n^{-}}$CMC core-shell microparticles was determined by SLS (Fig. 1). Two peaks were obtained in particle size distribution plot expressed in volume of particles vsparticle size. The first one corresponded to $0.2 \mu \mathrm{m}$ and the second one to $1.0 \mu \mathrm{m}$ (Fig. 1a). Particle size distribution expressed in number, which indicates the contribution of number of particles presents into each population to the global distribution, displayed only a dominant peak (Fig. 1b). This peak corresponded to the majority of particles which resulted to have the smallest diameter. Characteristics diameters for core-shell microparticles, $\mathrm{D}_{32}$ and $\mathrm{D}_{43}$, were $0.195 \pm 0.002 \mu \mathrm{m}$ and $0.236 \pm 0.003 \mu \mathrm{m}$, respectively. These results are coincident with the obtained in the previous work [10].

\subsection{Water Holding Capacity}

WHC is one of most important yoghurt properties because is related to the product stability [27]. Even WHC and gel syneresis are conceptually different, they are related, i.e. a well-structured gel will have a high WHC and scarce syneresis [28]. Table $\mathbf{3}$ displayed WHC values obtained for the studied formulations. In general terms, CS and the commercial yoghurts constituted a statistically coherent group with higher WHC than F and L yoghurts which constituted a different group. Lower WHC values obtained in F and L yoghurts could be attributed to the lack of stabilizers in their formulations. No significant differences were observed in
WHC values in relation to fat content into each group. Biopolymers addition such as gelatin, pectin, microcrystalline cellulose and the remaining CMC chains in the CS case, would contribute to this behavior by increasing viscosity. Storage time exerted little effect on WHC.
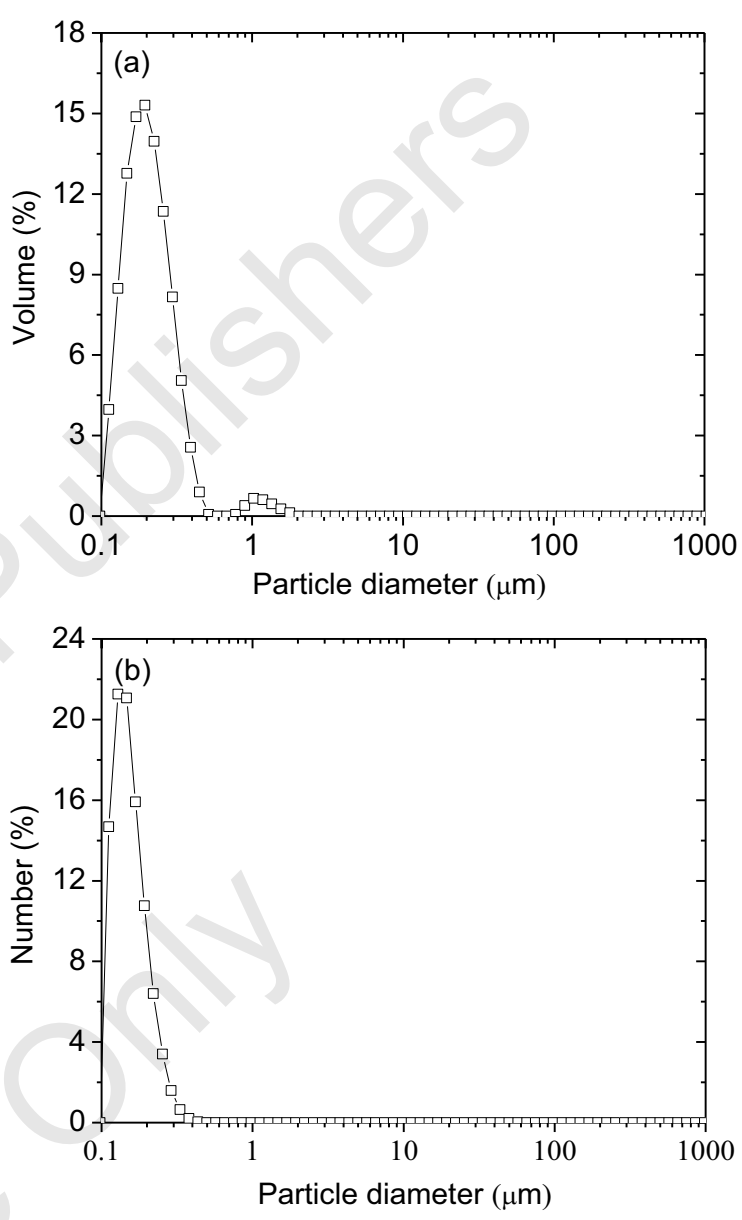

Fig. (1). Volume (a) and number (b) size distribution of $\left[(\beta-\lg )_{\mathrm{n}}\right.$ $0.25 \% \mathrm{w} / \mathrm{w}+\mathrm{CMC} 0.3 \% \mathrm{w} / \mathrm{w}$ ] core-shell microparticles in aqueous solution. $\mathrm{pH} 4$ and temperature $25^{\circ} \mathrm{C}$.

\subsection{Colour Parameters}

Microparticles could have a different refractive index (IR) to that of surrounding food media, being able to alter its optical properties. Although, the effect of microparticle incorporation will depend on their concentration, size and IR [29]. Table 4 shows L*, a* and b* parameters for each studied formulation and during storage time. Samples did not show great differences between them concerning to $\mathrm{L}^{*}$ values, which ranged 67-74. No significant changes were observed upon time. FC1 showed the highest and CS the lowest values. There is not agreement about this topic in literature. Thus, Arancibiaet al. [30] and Vargas et al. [31] pointed out fat content increase the whiteness in dairy products. On the other hand, Aportela-Palacios et al. [32] found a decrease for $\mathrm{L}^{*}$ value with fat content increase. Our measurements did not show a clear trend concerning to the impact of fat replacement on $\mathrm{L}^{*}$ parameter in the analyzed groups, for instance $\mathrm{FC} 1$ presented a higher $\mathrm{L}^{*}$ in comparison with samples containing a similar fat content. 
Table 3. Water holding capacity (WHC, \%) of yoghurts upon storage time. F: full fat; L: low fat; CS: core-shell; LC1: $1^{\text {st }}$ commercial brand low fat set yoghurt; LC2: $2^{\text {nd }}$ commercial brand low fat set yoghurt; FC1: $1^{\text {st }}$ commercial brand full fat set yoghurt and FC2: $2^{\text {nd }}$ commercial brand full fat set yoghurt.

\begin{tabular}{|c|c|c|c|c|c|c|c|}
\hline \multicolumn{7}{|c|}{ WHC (\%) } \\
\hline Day & F & L & CS & LC1 & LC2 & FC1 & FC2 \\
\hline \hline 7 & $56.0 \pm 4.9^{\mathrm{a}, \mathrm{A}}$ & $56.8 \pm 0.7^{\mathrm{b}, \mathrm{A}}$ & $99.5 \pm 0.1^{\mathrm{a}, \mathrm{E}}$ & $76.8 \pm 0.1^{\mathrm{a}, \mathrm{B}}$ & $73.4 \pm 1.5^{\mathrm{a}, \mathrm{B}}$ & $84.1 \pm 1.2^{\mathrm{a}, \mathrm{C}}$ & $92.8 \pm 0.4^{\mathrm{a}, \mathrm{D}}$ \\
\hline 21 & $64.6 \pm 6.2^{\mathrm{a}, \mathrm{A}, \mathrm{B}}$ & $50.5 \pm 0.4^{\mathrm{a}, \mathrm{A}}$ & $88.0 \pm 13.1^{\mathrm{a}, \mathrm{C}}$ & $77.5 \pm 8.6^{\mathrm{a}, \mathrm{B}, \mathrm{C}}$ & $81.6 \pm 5.3^{\mathrm{b}, \mathrm{C}}$ & $82.6 \pm 2.8^{\mathrm{a}, \mathrm{C}}$ & $93.2 \pm 6.4^{\mathrm{a}, \mathrm{C}}$ \\
\hline
\end{tabular}

Means with different lowercase letters within the same column differed significantly $(\mathrm{p}<0.05)$

Means with different uppercase letters within the same file differed significantly $(\mathrm{p}<0.05)$.

Table 4. Colour parameters, $L^{*}, a^{*}$ and $b^{*}$, of yoghurts upon storage time. F: full fat; L: low fat; CS: core-shell; LC1: $1^{\text {st }}$ commercial brand low fat set yoghurt; LC2: $2^{\text {nd }}$ commercial brand low fat set yoghurt; FC1: $1^{\text {st }}$ commercial brand full fat set yoghurt and FC2: $2^{\text {nd }}$ commercial brand full fat set yoghurt.

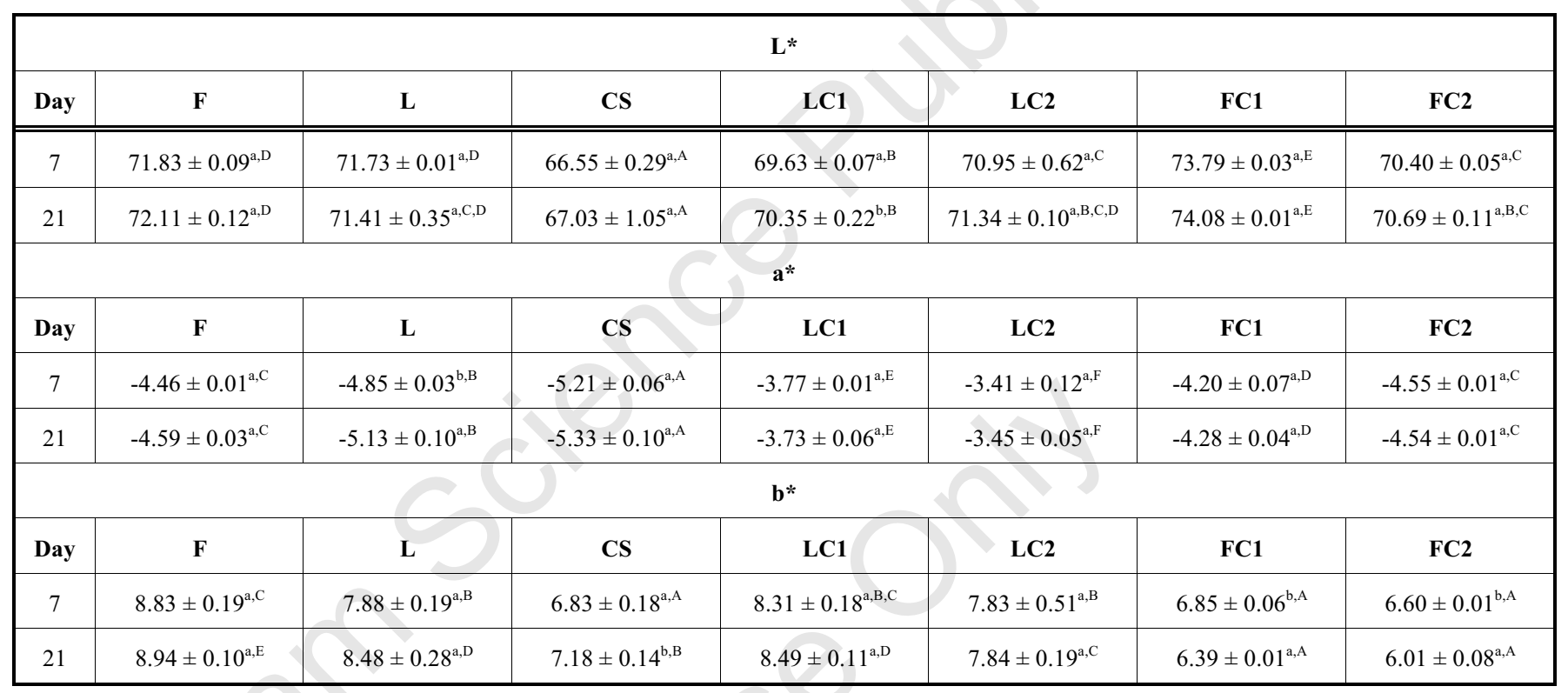

Means with different lowercase letters within the same column differed significantly in terms of formulation $(p<0.05)$.

Means with different uppercase letters within the same file differed significantly upon storage time $(\mathrm{p}<0.05)$.

Regarding a* parameter, all samples presented negative values; being commercial yoghurts lower than $\mathrm{CS}, \mathrm{F}$ and $\mathrm{L}$ samples. Between commercial yoghurts, FC1 and FC2 showed higher trend to the green colour than LC1 and LC2 yoghurts. Yazici et al. [33] explained that fat content would contribute to green colour. Syneresis could also contribute to enhance the negative $a^{*}$ value. $L$ yoghurt that presented more syneresis, releasedmore riboflavin in whey, which has an important green component and enhancing the negative values for $\mathrm{a}^{*}$ parameter [34]. Similarly to $\mathrm{L}^{*}$ parameter, no significant changes were detected for $\mathrm{a}^{*}$ upon storage time.

All formulations had positive values of $b^{*}$ parameter. Several studies indicated that as fat content decrease, the yellow color also decrease in dairy products $[30,33]$ which is in line with the values obtained for $\mathrm{F}$ sample. However, $\mathrm{FC} 1, \mathrm{FC} 2$ and $\mathrm{CS}$ formulations manifested lower $\mathrm{b}^{*}$ values. The presence of curcuma and rocu, as stated in the composition label, in LC1 and LC2 yoghurts would explain the higher trend to yellow colour. Storage time did not manifested significant effects, contrarily to Lee et al. [34] who claimed that storage at $4{ }^{\circ} \mathrm{C}$ enhance $b^{*}$ values.

\subsection{Textural Parameters}

Fat content reduction can alter mechanical-sensorial properties [35] since fat matter interacts with the protein network [36]. Concomitantly, biopolymeric particles incorporation can affect rheology and texture of food [37]. Table 5 refers to textural parameters obtained from back extrusion assay. Only textural properties that manifested changes between samples and/or upon storage time are analyzed. Measurements were done at 7 and 21 days of storage. CS and FC2 showed the lowest values in firmness parameter. In fact, fermentation times resulted $2.5 ; 4.5$ and $8 \mathrm{~h}$, for F, L, and CS formulations, respectively. Hydrocolloids as $\mathrm{Na}-\mathrm{CMC}$ could have a destabilizer effect on casein micelle. Being this fact another reason for the $\mathrm{CS}$ gel weakness. It is an interplay as CMC presence kept the WHC values in low levels without avoiding the complete caseins aggregation impeded by the same polysaccharide [18], i.e. gel formation occurred. Thus, an opener microstructure with no homogeneous aggregates could be formed. L yoghurts had the highest values for firmness parameter, which in turn had the highest nonfat solids content (Table 1). In fact, casein/whey protein ratio decrease 
Table 5. Instrumental textural properties (firmness, cohesiveness and adhesiveness) variation of yoghurts upon storage time.F: full fat; L: low fat; CS: core-shell; LC1: $1^{\text {st }}$ commercial brand low fat set yoghurt; LC2: $2^{\text {nd }}$ commercial brand low fat set yoghurt; FC1: $1^{\text {st }}$ commercial brand full fat set yoghurt and FC2: $2^{\text {nd }}$ commercial brand full fat set yoghurt.

\begin{tabular}{|c|c|c|c|c|c|c|c|}
\hline \multicolumn{8}{|c|}{ Firmness (g) } \\
\hline 7 & $238.43 \pm 12.6^{\mathrm{a}, \mathrm{B}}$ & $447.89 \pm 9.0^{\mathrm{a}, \mathrm{C}}$ & $137.26 \pm 0.4^{\mathrm{a}, \mathrm{A}}$ & $263.56 \pm 24.7^{\mathrm{a}, \mathrm{B}}$ & $254.94 \pm 16.2^{\mathrm{a}, \mathrm{B}}$ & $248.35 \pm 34.9^{\mathrm{a}, \mathrm{B}}$ & $99.83 \pm 12.1^{\mathrm{a}, \mathrm{A}}$ \\
\hline 21 & $241.05 \pm 2.5^{\mathrm{a}, \mathrm{B}}$ & $476.28 \pm 37.4^{\mathrm{a}, \mathrm{D}}$ & $134.24 \pm 22.6^{\mathrm{a}, \mathrm{A}}$ & $317.25 \pm 10.1^{\mathrm{a}, \mathrm{C}}$ & $255.51 \pm 32.3^{\mathrm{a}, \mathrm{B}}$ & $280.32 \pm 27.0^{\mathrm{a}, \mathrm{B}, \mathrm{C}}$ & $138.42 \pm 9.6^{\mathrm{a}, \mathrm{A}}$ \\
\hline \multicolumn{8}{|c|}{ Cohesiveness } \\
\hline 7 & $-79.6 \pm 1.1^{\mathrm{a}, \mathrm{A}, \mathrm{B}}$ & $-91.0 \pm 10.3^{\mathrm{a}, \mathrm{A}}$ & $-94.5 \pm 1.0^{\mathrm{a}, \mathrm{A}}$ & $-63.6 \pm 0.1^{\mathrm{a}, \mathrm{C}}$ & $-72.6 \pm 2.1^{\mathrm{a}, \mathrm{B}, \mathrm{C}}$ & $-83.9 \pm 3.1^{\mathrm{a}, \mathrm{A}, \mathrm{B}}$ & $-44.0 \pm 14.0^{\mathrm{a}, \mathrm{D}}$ \\
\hline 21 & $-83.5 \pm 18.2^{\mathrm{a}, \mathrm{A}, \mathrm{B}}$ & $-113.1 \pm 48.7^{\mathrm{a}, \mathrm{A}}$ & $-88.6 \pm 6.0^{\mathrm{a}, \mathrm{A}, \mathrm{B}}$ & $-67.0 \pm 2.7^{\mathrm{a}, \mathrm{A}, \mathrm{B}}$ & $-66.4 \pm 9.9^{\mathrm{a}, \mathrm{B}}$ & $-84.5 \pm 0.2^{\mathrm{a}, \mathrm{A}, \mathrm{B}}$ & $-50.8 \pm 9.5^{\mathrm{a}, \mathrm{B}}$ \\
\hline \multicolumn{8}{|c|}{ Adhesiveness ( $\mathrm{g} \times \mathrm{sec})$} \\
\hline Day & $\mathbf{F}$ & $\mathbf{L}$ & CS & LC1 & $\mathrm{LC2}$ & FC1 & FC2 \\
\hline
\end{tabular}

Means with different lowercase letters within the same column differed significantly in terms of formulation $(\mathrm{p}<0.05)$.

Means with different uppercase letters within the same file differed significantly upon storage time $(\mathrm{p}<0.05)$.

would cause the gel firmness increase after thermal treatment [38]. F yoghurts showed a firmness character similar to the commercial ones.

On the contrary, the fat replacer Simplesse ${ }^{\circledR} 100$, containing $50.5 \%$ of microparticulated whey proteins, provoked a firmness decreasewith a higher cohesiveness in low fat yoghurts [36]. This fat replacer mimics the globules with few milk proteins interactions, that is why yoghurt displayed an opener and less dense network [39].

The comparison of cohesiveness and adhesiveness parameters for different samples and upon time is also shown in Table 5. Three groups can be distinguished concerning to cohesiveness property, the first constituted by L and CS which resulted the more cohesive samples. The second group constituted by FC2 sample that showed the lowest cohesiveness. The remaining samples placed between these two groups. CS displayed the highest adhesiveness value at the initial storage time although it tended to the commercial yogurts after 21 days. High hydration capacity of CMC chains forming the shell of particles would be the reason for that trend. It was previously reported that the increase for water adsorption capacity in protein matrices enhance the cohesiveness [40]. Lower cohesiveness values could be related with the interference exerted by the remnant long chains of the polysaccharide into the enriched protein matrix; specifically during the 3-dimensional casein structure formation. Similar result was reported by Vanegas-Azuero and Gutiérrez [41] who examinated the effect of $\beta$-glucans on yoghurts.

$\mathrm{F}, \mathrm{L}$ and $\mathrm{FC} 1$ yoghurts were similarly adhesive. In general, samples adhesiveness decrease with time, showing statistically significant differences only for CS case. Hashim et al. [42] also reported a decrease in adhesiveness and cohesiveness in yoghurts enriched with date fiber. Although this was not a general rule as Ale et al. [43] did not found significant differences in adhesiveness for yoghurts containing an exopolysaccharide extract from Lactobacillus fermentumLf2 and the respective control, even upon storage time.

\subsection{Mechanical Spectra}

Oscillatory tests are widely accepted for rheological characterization of yoghurt, which is a typical example of a weak gel. $G^{\prime}$ predominanceover $G^{\prime \prime}$ corresponds to a quality feature for a correctly elaborated product [38]. Figure (2) shows the $\mathrm{G}^{\prime}$ dependence with frequency, which is an example of gel behavior for yoghurt samples. Table 6 present $\mathrm{G}^{\prime}$ values taken at $1 \mathrm{~Hz}$ of frequency from mechanical spectrum of each sample, and $n$ values obtained by linearizing mechanical spectra data by application of Eq. 2 [24].

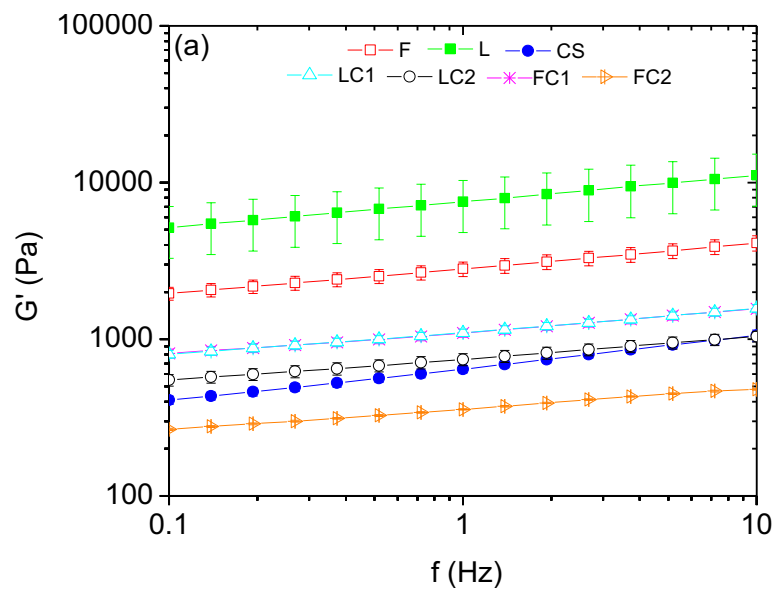

Fig. (2). Elastic modulus $\left(\mathrm{G}^{\prime}\right)$ as function of frequency (spectrum measured between 0.1 and $10 \mathrm{~Hz}$ ) of yoghurts upon storage time. $\mathrm{F}$ : full fat; L: low fat; CS: core-shell; LC1: $1^{\text {st }}$ commercial brand low fat set yoghurt; LC2: $2^{\text {nd }}$ commercial brand low fat set yoghurt; FC1: $1^{\text {st }}$ commercial brand full fat set yoghurt and FC2: $2^{\text {nd }}$ commercial brand full fat set yoghurt. 
Table 6. G' (Pa) taken at $\mathbf{f}=1 \mathrm{~Hz}$ from each mechanical spectra (Fig. 2) and $\mathbf{n}$ values derived from fitting experimental data by $\mathbf{E}$. 2. F: full fat; L: low fat; CS: core-shell; LC1: $1^{\text {st }}$ commercial brand low fat set yoghurt; LC2: $2^{\text {nd }}$ commercial brand low fat set yoghurt; FC1: $1^{\text {st }}$ commercial brand full fat set yoghurt and FC2: $2^{\text {nd }}$ commercial brand full fat set yoghurt.

\begin{tabular}{|c|c|c|c|c|c|c|c|}
\hline \multicolumn{8}{|c|}{$\mathbf{G}^{\prime}(\mathbf{P a})$} \\
\hline 7 & $2810.0 \pm 297.0^{\mathrm{a}, \mathrm{A}}$ & $7555.0 \pm 2764.8^{\mathrm{a}, \mathrm{B}}$ & $644.5 \pm 34.6^{\mathrm{a}, \mathrm{A}}$ & $743.0 \pm 66.5^{\mathrm{a}, \mathrm{A}}$ & $1095.0 \pm 63.6^{\mathrm{a}, \mathrm{A}}$ & $1100.0 \pm 56.6^{\mathrm{a}, \mathrm{A}}$ & $356.5 \pm 3.5^{\mathrm{a}, \mathrm{A}}$ \\
\hline 21 & $3650.0 \pm 636.4^{\mathrm{a}, \mathrm{B}}$ & $8523.3 \pm 1466.4^{\mathrm{a}, \mathrm{C}}$ & $764.5 \pm 65.8^{\mathrm{a}, \mathrm{A}}$ & $866.0 \pm 45.3^{\mathrm{a}, \mathrm{A}}$ & $1223.3 \pm 85.0^{\mathrm{a}, \mathrm{A}}$ & $1305.0 \pm 134.4^{\mathrm{a}, \mathrm{A}}$ & $437.5 \pm 24.7^{\mathrm{a}, \mathrm{A}}$ \\
\hline \multicolumn{8}{|c|}{$\mathbf{n}$} \\
\hline 7 & $0.160 \pm 0.003^{\mathrm{b}, \mathrm{D}}$ & $0.166 \pm 0.001^{\mathrm{b}, \mathrm{E}}$ & $0.208 \pm 0.002^{\mathrm{a}, \mathrm{F}}$ & $0.140 \pm 0.001^{\mathrm{a}, \mathrm{B}}$ & $0.144 \pm 0.001^{\mathrm{a}, \mathrm{C}}$ & $0.146 \pm 0.001^{\mathrm{b}, \mathrm{C}}$ & $0.133 \pm 0.000^{\mathrm{a}, \mathrm{A}}$ \\
\hline 21 & $0.153 \pm 0.002^{\mathrm{a}, \mathrm{B}}$ & $0.160 \pm 0.002^{\mathrm{a}, \mathrm{C}}$ & $0.212 \pm 0.002^{\mathrm{a}, \mathrm{D}}$ & $0.140 \pm 0.003^{\mathrm{a}, \mathrm{A}}$ & $0.140 \pm 0.003^{\mathrm{a}, \mathrm{A}}$ & $0.139 \pm 0.003^{\mathrm{a}, \mathrm{A}}$ & $0.135 \pm 0.003^{\mathrm{a}, \mathrm{A}}$ \\
\hline
\end{tabular}

Means with different lowercase letters within the same column differed significantly in terms of formulation $(\mathrm{p}<0.05)$.

Means with different uppercase letters within the same file differed significantly upon storage time $(\mathrm{p}<0.05)$.

L showed the highest $\mathrm{G}^{\prime}$ values followed by $\mathrm{F}$ and then the other yoghurts formulations. No significant changes were detected for $\mathrm{G}^{\prime}$ upon storage time. CS rheological parameters were similar to commercial yoghurts; which is important for a new product that resembles to the existing ones for consumer acceptance. Anionic polysaccharides, CMC in this case, can interact electrostatically with aggregates formed by micelles, which generate different effects on product rheology. Gelation process and network formation can be modified by the polysaccharide as they could stabilize the tridimensional structure. The extent of this phenomenon will depends on the specific polysaccharide molecular properties such charge density, if it was a charged polysaccharide, and chain rigidity [44]. Formation of bridges between neighbor protein aggregates would increase $\mathrm{G}^{\prime}$ values $[44,45]$. Other reports attributed the $G^{\prime}$ increase to solids content enhancement concomitantly with casein molecules aggregation [46].

$n$ value is considered an indicator of the viscoelastic nature of gels. For instance, $n=0$ occurred in purely elastic gels and $n>0$ indicates a more important contribution of viscous component of the gel matrix [47]. Thus, Table 6 displayed $n$ values for all the formulation upon storage time. Statistically significant decrease was only found for F, L and FC1 yoghurts. CS showed the highest values for $n$ parameter $(\sim 0.21)$. F and L samples resulted significantly higher than the commercial samples. These results demonstrated a lower solid character of gels and a higher relaxation bonds [48] for CS yoghurts.

\subsection{Yoghurt Microstructure}

CLSM has proven to be a very useful tool for the study of the food microstructure. In fact, it has been used to investigate the microstructure of gels, such as yoghurt in numerous studies [49]. Figure (3) shows the microstructures of yoghurts F, L and CS at 7 days of storage. Rhodamine B staining of the protein network is shown in green while fat content is stained with Congo Red and shown in red. A dense, continuous and homogeneous network, consisting of fat and protein aggregates was evident in yogurt $\mathrm{F}$ (Figs. 3ac). It has been demonstrated that, in dairy gels acidified with glucono delta lactone, fat globules were dispersed around the gel, suggesting its positive interaction with the network [50]. Microstructure of L formulation (Figs. 3d-f) was found to be similar to $F$, with a more compact protein network and smaller aggregates. According toMatumoto-Pintro et al. [51], homogeneous distribution of protein material would be a consequence of little contraction during network formation. The microstructure corresponding to the CS formulation (Figs. 3g-i) showed a discontinuous and less dense protein network, as compared with the previous microstructures. These results are consistent with the lower value for firmness in CS compared to F and L yoghurts. Formulations containing skim milk (L and CS) some partsdyed with Congo Red could be observed since it contain traces of fat [52]. In fact, there is remaing lipid material in the isolated $\beta-\lg$ forming the core of microparticles. According with our results, Aziznia et al. [53] found that addition of tragacanth, as a fat substitute in yoghurts, increased the distance between the casein particles, avoiding their contact between them and causing a decrease in the strength of gel. Finally, after 21 days of storage, no noticeable changes are observed in formulations corresponding to $\mathrm{F}$ and $\mathrm{L}$ yoghurt (Figs. 4a-h). However, in the CS formulation (Figs. 4g-i) an increase in the volume of the aggregates together with a decrease in serum rich areas could be observed. This could be explained by the hydrophilicity of CMC. Over time, the polysaccharide chains located on the outside of the core-shell particles continued capturing serum, increasing their size by hydration consequently.

\subsection{Bacterial Growth}

Yoghurt flavour depends on the production of lactic acid, acetic acid, and acetaldehyde during fermentation and the starter culture ( $S$. thermophilus and L. delbrueckii subsp. bulgaricus). In particular, L. delbrueckii is mainly responsible for the production of acetaldehyde [38]. Microbial growth, acidification, flavour production and nutritional benefits continue during storage time [54]. That is the reason why the knowledge number of viable microorganism is a crucial factor in the final product.

Bacterial growth for the three yoghurt formulations (F, L and CS) with time: 7 and 21 days, are shown in Fig. (5). The 


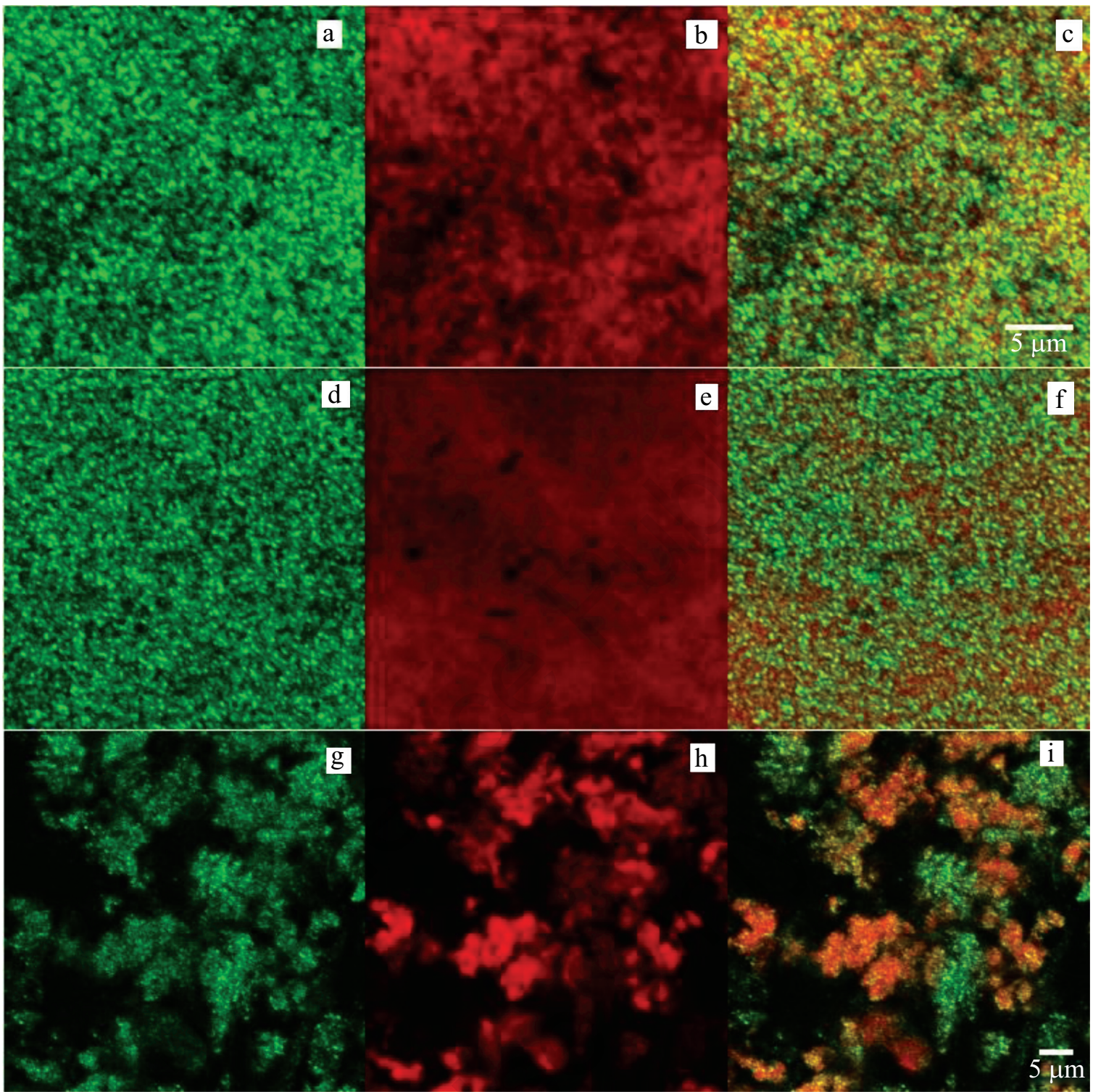

Fig. (3). Confocal laser scanning micrographs of magnified (10x zoom) microstructures of set yoghurts. Enhanced CLSM images for green corresponding to fat phase $(\mathbf{a}, \mathbf{d}, \mathbf{g})$ and red to protein phase $(\mathbf{b}, \mathbf{e}, \mathbf{h})$ channels and their overlay $(\mathbf{c}, \mathbf{f}, \mathbf{i})$ taken using $60 \mathrm{X}$ oil immersion lens $($ N.A. $=1.2)$, scale bar $=5 \mu \mathrm{m} .1^{\text {st }}$ column F sample; $2^{\text {nd }}$ column L sample and $3^{\text {th }}$ column CS sample. Samples had been kept at $4{ }^{\circ} \mathrm{C}$ for 7 days up to observation. (The color version of the figure is available in the electronic copy of the article).

initial value of starter culture was $2.90 \mathrm{E}+06 \mathrm{CFU} / \mathrm{mL}$. Data are consistent with those reported by Robinson et al. [38], with a viable plate count from $1.0 \mathrm{E}+06$ to $1.0 \mathrm{E}+08$ $\mathrm{CFU} / \mathrm{g}$. The results indicate an increase in bacterial population for all formulations. There was a higher increment in bacterial growth in the F sample. This founding suggests that the presence of fatty acid promoting the development of lactic acid bacteria, which coincides with the shortest time fermentation and its acidity profile. Growth in the CS formulation was greater or equal than L yoghurt, so we can affirm that the core-shell microstructures do not prevent the development of the starter culture. In line, Caetano-Silva et al. [55] reported that the addition of whey protein-CMC coacervates in probiotic fermented milk was feasible and did not interfere with the Bifidobacterium animalis subsp. lactis and $S$. thermophilus viability, even $S$. thermophilus is characterized for having low proteolytic activity, and therefore requires free amino acids for growth.

\section{CONCLUSION}

This study demonstrated the feasibility of using coreshell microparticles, constituted by a core of aggregated $\beta-1 g$ surrounded by $\mathrm{CMC}$, as a fat matter replacer in set type yoghurt. Yoghurt formulations prepared with whole and skim milk were compared with commercial yoghurts, which were used as controls.

Fermentation time of yoghurt increased with core-shell microparticles addition. CMC is likely to increase the buffer capacity of the system, slowing the rate of acidification. Chromatic parameters did not show significant changes over time.

The core-shell microparticles also influence the textural properties of yoghurt. Firmness of CS samples was similar to the commercial yoghurt but lower than F and L lab-made yoghurts. WHC values were also similar to the corresponding 


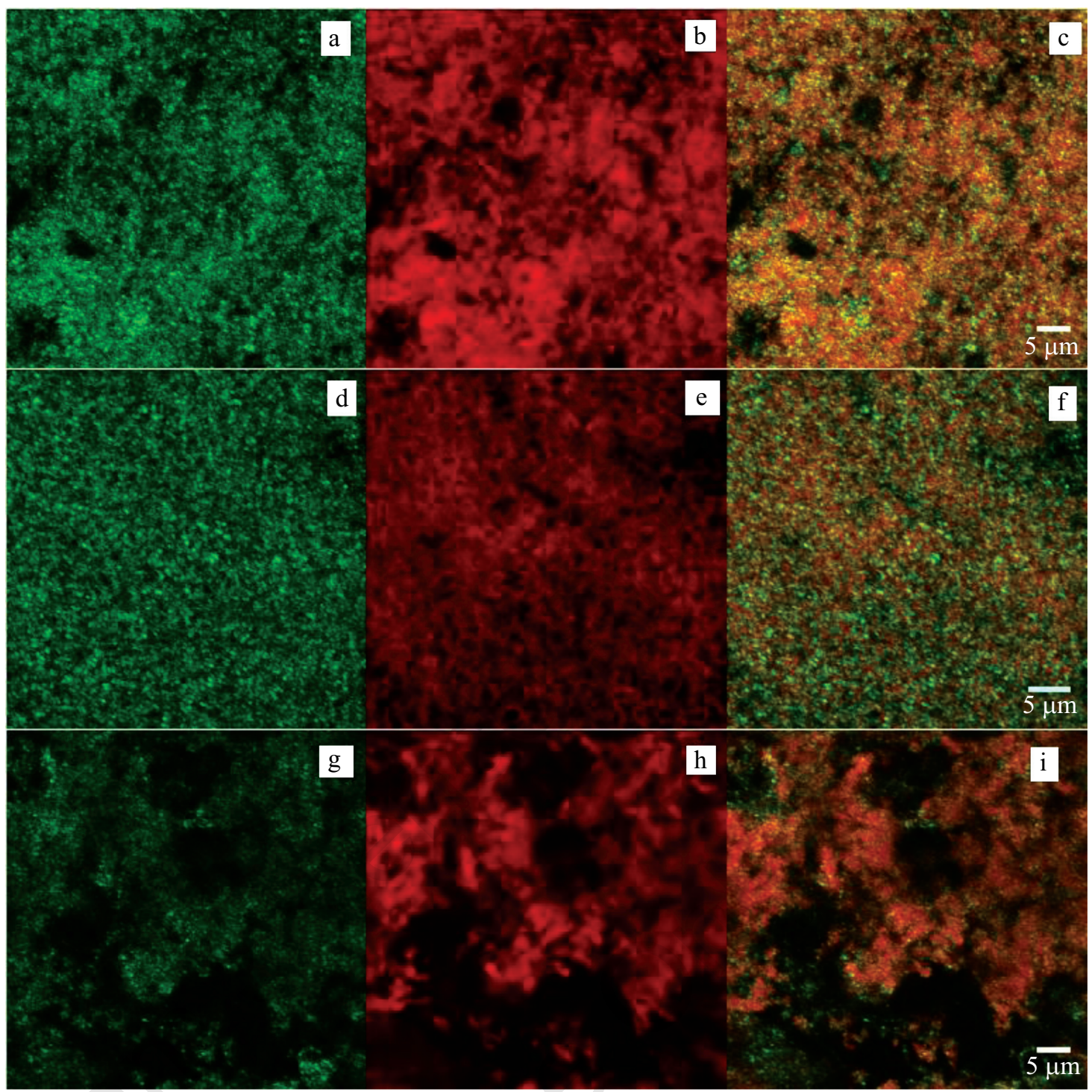

Fig. (4). Confocal laser scanning micrographs of magnified (10x zoom) microstructures of set yoghurts. Enhanced CLSM images for green corresponding to fat phase (a, d, g) and red, protein phase (b,e, h) channels and their overlay (c, f, i) taken using 60X oil immersion lens $($ N.A. $=1.2)$, scale bar $=5 \mu \mathrm{m} .1^{\text {st }}$ column F sample; $2^{\text {nd }}$ column L sample and $3^{\text {rd }}$ column CS sample. Samples had been kept at $4{ }^{\circ} \mathrm{C}$ for 21 days up to observation. (The color version of the figure is available in the electronic copy of the article).

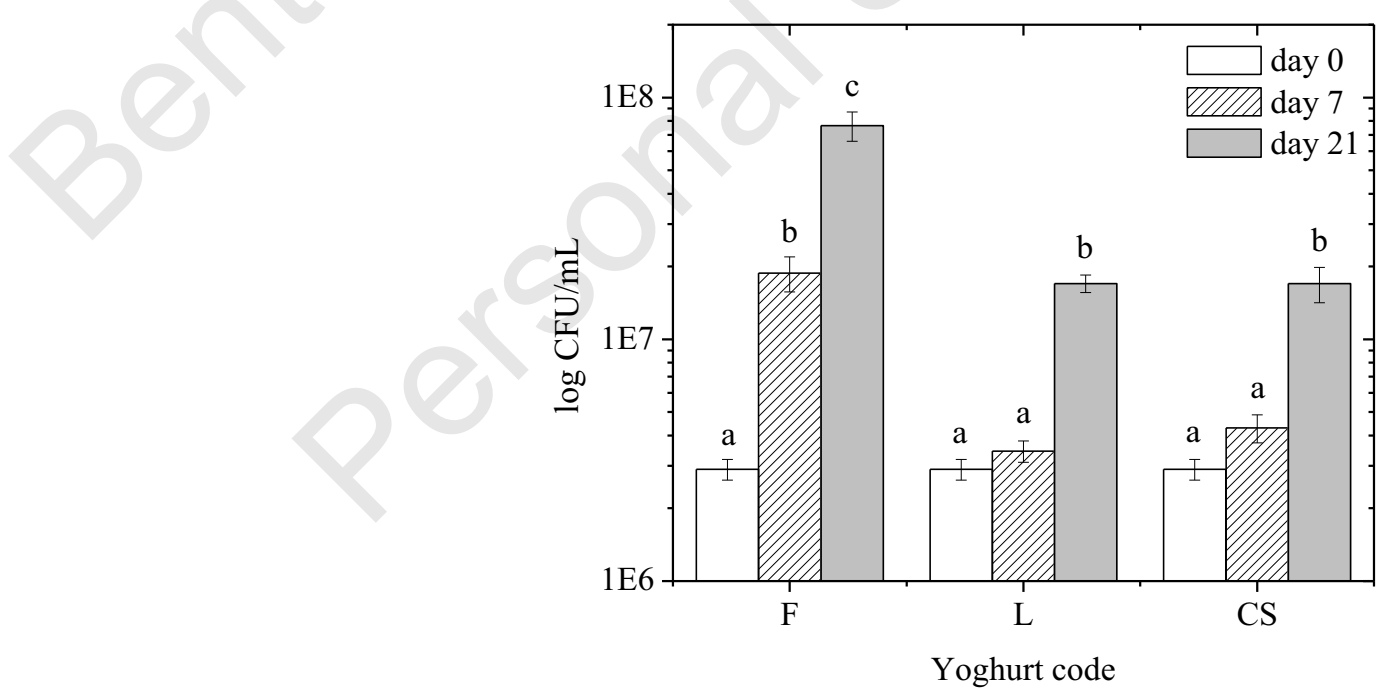

Fig. (5). Bacterial growth determined in F, L, CS yoghurts, for 1, 7 and 21 days. Means with different letters are significantly different $(\mathrm{p}<0.05)$ 
commercial products. The most plausible explanation is that the shell of microparticles, which was formed by chains of $\mathrm{CMC}$, captured whey and the syneresis process slowed down.

Rheological parameters for CS yoghurt kept correspondence with a weak gel, as demonstrated by rheological test. Yoghurt microstructure showed that the incorporation of the core-shell microparticles generated a discontinuous protein network, with a less dense matrix than the F and L yoghurt. An increase in aggregates microzones and decrease of serum rich regions was noted over time. Replacement of fat by core-shell microparticles delayed fermentation; however, $\mathrm{CFU} / \mathrm{mL}$ resulted in an $\mathrm{L}$ formulation significantly similar to the throughout storage time.

In summary, these are promising results since they could enhance the chance of CS yoghurts acceptance by consumers. We also hypothesize that it would be possible to encapsulate bioactive compounds in the core or shell of these microparticles exerting a controlled release thereof. These bioactive compounds could even be a prebiotic for bacteria, favoring in this way the increase in fermentation rate. This work is part of a more extensive project which also includes sensory analysis of the samples and digestibility studies that are being carried out. Moreover, the scaling up process also involves challenges for the CS yoghurt production.

\section{ETHICS APPROVAL AND CONSENT TO PARTICI- PATE}

Not applicable.

\section{HUMAN AND ANIMAL RIGHTS}

No Animals/Humans were used for studies that are the basis of this research.

\section{CONSENT FOR PUBLICATION}

Not applicable.

\section{CONFLICT OF INTEREST}

The authors declare no conflict of interest, financial or otherwise.

\section{ACKNOWLEDGEMENTS}

This work has been performed with the support of the Consejo Nacional de Investigaciones Científicas y Técnicas, the Agencia Nacional de Promoción Científica y Tecnológica (PICT 2013-1985, 2014-3304 and 2015-3866) and Universidad de Buenos Aires Argentina (UBACyT, 200201501000 79BA).

\section{SUPPLEMENTARY MATERIAL}

Supplementary material is available on the publisher's web site along with the published article.

\section{REFERENCES}

[1] Mukhopadhyay $\mathrm{P}$, Chakraborty S, Bhattacharya S, et al. pHsensitive chitosan/alginate core-shell nanoparticles for efficient and safe oral insulin delivery. Int J Biol Macromol 2015; 72: 640-48.
[2] Prudkin-Silva CP, Martínez JH, Martínez KD, et al. Proposed molecular model for electrostatic interactions between insulin and chitosan. Nano-complexation and activity in cultured cells. Coll Surf A-Physicochem Eng Asp 2018; 537: 425-34.

[3] Capitani C, Perez OE, Bertoldo-Pacheco MT, et al. Influence of complexing carboxymethylcellulose on the thermostability and gelation of alpha-lactalbumin and beta-lactoglobulin. Food Hydrocoll 2006; 21: 1344-54.

[4] Aravind N, Sissons M, Fellows CM. Effect of soluble fibre (guar gum and carboxymethylcellulose) addition on technological, sensory and structural properties of durum wheat spaghetti. Food Chem 2012; 131: 893-900.

[5] Su J-F, Huang Z, Yuan X-Y, et al. Structure and properties of carboxymethyl cellulose/soy protein isolate blend edible films crosslinked by Maillard reactions. Carbohydr Polym 2010; 79: 14553.

[6] Huan Y, Zhang S, Vardhanabhuti B. Influence of the molecular weight of carboxymethylcellulose on properties and stability of whey protein-stabilized oil-in-water emulsions. J Dairy Sci 2016; 99: 3305-15.

[7] Vazconez MB, Flores SK, Campos CA, et al. Antimicrobial activity and phisical properties of chitosan-tapioca stache based edible films and coatings. Food Res Int 2009; 42: 762-9.

[8] Shpigelman A, Cohen Y, Livney YD. Thermally-induced $\beta$ lactoglobulin-EGCG nanovehicles: Loading, stability, sensory and digestive-release study. Food Hydrocoll 2012; 29: 57-67.

[9] Das B, Sarkar S, Sarkar A, et al. Recovery of whey proteins and lactose from dairy waste: A step towards green waste management Process Saf Environ Prot 2016; 101: 27-33.

[10] Carpineti L, Martinez MJ, Pilosof AMR, et al. $\beta$-Lactoglobulincarboxymethylcellulose core-shell microparticles: Construction, characterization and isolation, J Food Eng 2014; 131: 65-74.

[11] Sarkar D, Sen D, Nayak BK, et al. Spray-dried encapsulated starch and subsequent synthesis of carbon-silica core-shell microgranules. Coll Surf A-Physicochem Eng Asp 2017; 529: 696-704.

[12] Santipanichwong R, Suphantharika M, Weiss J, et al. Core-shell biopolymer nanoparticles produced by electrostatic deposition of beet pectin onto heat-denatured b-lactoglobulin aggregates. J Food Sci 2008; 73(6): 23-30.

[13] Shewan HM, Stokes JR. Review of techniques to manufacture micro-hydrogel particles for the food industry and their applications. J Food Eng 2013; 119: 781-92.

[14] Huang X, Kakuda Y, Cui W. Hydrocolloids in emulsions: particle size distribution and the interfacial activity. Food Hydrocoll 2001; 15: $533-42$.

[15] Leroux J, Langendorff V, Schick G, et al. Emulsion stabilizing properties of pectin. Food Hydrocoll 2003; 17: 455-62.

[16] Gu YS, Decker AE, McClements DJ. Production and characterization of oil-in-water emulsions containing droplets stabilized by multilayer membranes consisting of $\beta$-lactoglobulin, $1-$ carrageenan and gelatin. Langmuir 2005; 21: 5752-60.

[17] Güzey D, Kim HJ, McClements DJ. Factors influencing the production of $\mathrm{o} / \mathrm{w}$ emulsions stabilized by $\beta$-lactoglobulin-pectin membranes. Food Hydrocoll 2004; 18: 967-75.

[18] Tamime AY, Robinson RK. Yoghurt Science and Technology. Woodhead Publishing Ltd.: Cambridge 1999.

[19] Krzeminski A, Grobhable K, Hinrichs J. Structural properties of stirred yoghurt as influenced by whey proteins. LWT-Food Sci Technol 2011; 44: 2134-40.

[20] IDF. Internacional Dairy Federation 1997; Standard 99C

[21] Bhandari V, Singh H. Physical Methods. In: Fuquay JW, Fox PF, McSweeney PLH, Eds. Encyclopedia of Dairy Sciences. Vol. 1 Elsevier: Amsterdam, Netherlands 2011; pp. 248-55.

[22] Abbasi H, Mousavi ME, Ehsani MR, et al. Influence of starter culture type and incubation temperatures on rheology and microstructure of low fat set yoghurt. Int J Dairy Technol 2009; 62: 549-55.

[23] Sendra E, Kuri V, Fernández-López J, et al. Viscoelastic properties of orange fiber enriched yogurt as a function of fiber dose, size and thermal treatment. LWT-Food Sci Technol 2010; 43: 708-14.

[24] Stading M, Langton M, Hermansson AM. Inhomogeneous finestranded b-lactoglobulin gels. Food Hydrocoll 1992; 6: 455-70.

Ciron CIE, Gee VL, Kelly AL, et al. Modifying the microstructure of low-fat yoghurt by microfluidisation of milk at different pressures to enhance rheological and sensory properties. Food Chem 2012; 130: 510-19. 
[26] Dave RI, Shah NP. Evaluation of media for selective enumeration of Streptococcus thermophilus, Lactobacillus delbrueckii ssp. bulgaricus, Lactobacillus acidophilus, and Bifidobacteria. J Dairy Sci 1996; 79: 1529-36.

[27] Srisuvor N, Chinprahast N, Prakitchaiwattana C, et al. Effects of inulin and polydextrose on physicochemical and sensory properties of low-fat set yoghurt with probiotic-cultured banana purée. LWTFood Sci Technol 2013; 51: 30-36.

[28] Ramchandran L, Shah NP. Characterization of functional, biochemical and textural properties of synbiotic low-fat yogurts during refrigerated storage. LWT-Food Sci Technol 2010; 43: 81927.

[29] Jones OG, McClements DJ. Recent progress in biopolymer nanoparticle and microparticle formation by heat-treating electrostatic protein-polysaccharide complexes. Adv Coll Interface Sci 2011; 167: 49-62.

[30] Arancibia C, Castro C, Jublot L, et al. Colour, rheology, flavour release and sensory perception of dairy desserts. Influence of thickener and fat content. LWT-Food Sci Technol 2014; 62: 40816.

[31] Vargas M, Cháfer M, Albors A, et al. Physicochemical and sensory characteristics of yoghurt produced from mixtures of cows' and goats' milk. Int Dairy J 2008; 18: 1146-52.

[32] Aportela-Palacios A, Sosa-Morales ME, Vélez-Ruiz JF. Rheological and physicochemical behavior of fortified yogurt, with fiber and calcium. J Texture Stud 2005; 36: 333-49.

[33] Yazici F, Akgun A. Effect of some protein based fat replacers on physical, chemical, textural, and sensory properties of strained yoghurt. J Food Eng 2004; 62: 245-54.

[34] Lee S-Y, Ahn J, Kwak H-S. Effects of the extract yam powder addition on yogurt properties during storage. Korean J Food Sci Anim Resour 2011; 31: 66-73.

[35] Sandoval-Castilla O, Lobato-Calleros C, Aguirre-Mandujano E, et al. Microstructure and texture of yogurt as influenced by fat replacers. Int Dairy J 2004; 14: 151-9.

[36] Aguirre-Mandujano E, Lobato-Calleros C, Beristain CI, et al. Microstructure and viscoelastic properties of low-fat yoghurt structured by monoglyceride gels. LWT-Food Sci Technol 2009; 42: 938-44.

[37] Jones OG, Decker EA, McClements DJ. Formation of biopolymer particles by thermal treatment of b-lactoglobulin-pectin complexes. Food Hydrocoll 2009; 23: 1312-21.

[38] Robinson RK, Itsaranuwat P. Properties of Yoghurt and their Appraisal. In: Tamime AY, Ed. Fermented Milks. Blackwell Publishing Ltd: Hoboken, New Jersey, United States 2007; pp. 7694.

[39] Tamime AY, Kalab M, Muir DD, et al. The microstructure of setstyle, natural yogurt made by substituting microparticulate whey protein for milk fat. J Soc Dairy Technol 1995; 48: 107-11.

[40] Sahan Y, Gocmen D, Cansev A, et al. Chemical and technofunctional properties of flours from peeled and unpeeled oleaster
(Elaeagnus angustifolia L.). J Appl Bot Food Qual-Angew Bot 2015; 88: https://doi.org/10.5073/JABFQ.2015.088.007.

[41] Vanegas-Azuero AM, Gutiérrez LF. Physicochemical and sensory properties of yogurts containing sacha inchi (Plukenetia volubilis L.) seeds and $\beta$-glucans from Ganoderma lucidum. J Dairy Sci 2018; 101(2): 1020-33.

[42] Hashim IB, Khalil AH, Afifi HS. Quality characteristics and consumer acceptance of yogurt fortified with date fiber. J Dairy Sci 2009; 92: 5403-7.

[43] Ale EC, Perezlindo MJ, Pavón Y, et al. Technological, rheological and sensory characterizations of a yogurt containing an exopolysaccharide extract from Lactobacillus fermentum Lf2, a new food additive. Food Res Int 2016; 90: 259-67.

[44] Laneuville SI, Turgeon SL. Microstructure and stability of skim milk acid gels containing an anionic bacterial exopolysaccharide and commercial polysaccharides. Int Dairy J 2014; 37: 5-15.

[45] Girard M, Schaffer-Lequart C. Gelation of skim milk containing anionic exopolysaccharides and recovery of texture after shearing. Food Hydrocoll 2007; 21: 1031-40.

[46] Brennan CS, Tudorica CM. Carbohydrate-based fat replacers in the modification of the rheological, textural and sensory quality of yoghurt: comparative study of the utilisation of barley beta-glucan, guar gum and inulin. Int J Food Sci Technol 2008; 43: 824-33.

[47] Ikeda S, Foegeding EA. Dynamic viscoelastic properties of thermally induced whey protein isolate gels with added lecithin, Food Hydrocoll 1999; 13: 245-54

[48] Lucey JA. Formation and physical properties of milk protein gels. J Dairy Sci 2002; 85: 281-94.

[49] Puvanenthiran A, Stevovitch-Rykner C, McCann TH, et al. Synergistic effect of milk solids and carrot cell wall particles on the rheology and texture of yoghurt gels. Food Res Int 2014; 62: 701-8.

[50] Lucey JA, Tamehana M, Singh H, et al. Effect of interactions between denatured whey proteins and casein micelles on the formation and rheological properties of acid skim milk gels. J Dairy Res 1998; 65: 555-67.

[51] Matumoto-Pintro PT, Rabiey L, Robitaille G, et al. Use of modified whey protein in yoghurt formulations. Int Dairy J 2011; 21: 21-6.

[52] Hoffmann W. Cream - Manufacture. In: Fuquay JW, Fox PF, McSweeney PLH, Eds. Encyclopedia of Dairy Sciences. Vol. 1 Elsevier: Amsterdam, Netherlands 2011; pp. 912-9.

[53] Aziznia S, Khosrowshahi A, Madadlou A, et al. Texture of nonfat yoghurt as influenced by whey protein concentrate and Gum Tragacanth as fat replacers. Int J Dairy Technol 2009; 62: 405-10.

[54] Zare F, Boye JI, Orsat V, et al. Microbial, physical and sensory properties of yogurt supplemented with lentil flour. Food Res Int 2011; 44: 2482-8.

[55] Caetano-Silva M, Capitani C, Antunes A, et al. Whey proteincarboxymethylcellulose obtained by complex coacervation as an ingredient in probiotic fermented milk. Food Nutr Sci 2015; 6: 57180 